\title{
Impacts of the Global Crisis Period 2007- 2010 on the Automotive Industry in the Czech Republic
}

\author{
Sedláček Marek
}

\begin{abstract}
The main aim of this article was to analyse the possible intensity of dependency of the Czech Republic, or more precisely, its total economic indicator Gross Domestic Product on realized Sales sector of the automotive industry before crisis, during the crisis period (2007-2010) as well as after the crisis. There was also used the development analysis of individual total economic indicators in the Czech automotive industry in time. On the other hand, in the article there were found and analysed impacts of the global recession on the functioning of several chosen companies associated in the Automotive Industry Association of the Czech Republic at their interaction with this way developed macroeconomic surroundings.

The investigation was based on the development of company result indicator value (Sales) of the selected companies and the chosen macro indicator (Gross Domestic Product) when looking for their reciprocal dependency in the period mainly connected with the financial and economic crisis. In the contribution, an elementary analysis of the chosen indicator Sales was carried out. With the help of regress and correlation analysis there were further researched the relationships among this chosen indicator of company performance reciprocally with all the companies, the Automotive Industry Association of the Czech Republic as a whole, and the chosen macro-indicator representing the development of selected markets. For the following calculation of tested criteria, Cohen's Coefficient was used to be able to assess the effect of the group on the value variability of studied random quantity.
\end{abstract}

Key words: economic crises, performance, sales, result indicators, development

\section{INTRODUCTION}

The years of 2007 - 2010 in the world history will be primarily connected with the entrance and marks of financial crisis, secondarily with its expansion in the form of worldwide economic recession and with declining activity of most economic subjects (states, companies, consumers, etc.) in the real economies (Smrčka \& Artlová, 2012).

One, on global changes very sensitive and by this crisis affected sector, was the automotive industry (AI) globally and also the Czech automotive in local. The AI is one of the biggest industrial sectors in the Czech Republic and during its history there have been manufactured more than 12 mil. cars included passenger cars, trucks, buses and motorcycles. The Czech Republic is often called "automotive power" (Sedláček, 2012).

In that case also the companies and firms interested in the Czech AI were affected by the global crisis during the period 2007-2010. Great percentage of them was affected negatively. However, even there exist exceptions which managed to profit in the crisis years and keep or increase their 
own production, sales or profit. All in this article chosen and analyzed companies are also involved in the business of The Automotive Industry Association Czech (further only AutoSAP), whose total data was used supposing that companies' association in AutoSAP represents 85 $-90 \%$ of the automotive industry as the sector expressing production volume, export or number of workers. Based on the basic above mentioned data it is apparent that the entry and progress of the crisis respectively demand decrease and sales slump could have had certain relationship with the economy performance of the Czech Republic in its total.

The separate not less important chapter includes the facts connected with the company ability to react flexibly on changing conditions of macroeconomic surrounding and in the appropriate way to change its own corporate strategies towards keeping its own production, above sales or profit, growth etc.

\section{LITERATURE REVIEW}

\subsection{Dynamic balance and self-production in market economy}

Market economy in the environment of free market is the relationship of dynamic balance, i. e. polar symmetry based on premises of free exchange. The purchaser and seller are attracted by the interest in the product (its sale, respectively purchase) and at the same time they are kept away by opposite interest in the price of the product (Vrecion, 2008). These polar and basically symmetric powers create this relationship. The intensity of interest during thinking and negotiation about the exchange is balanced and stabilized. The interest balance is completed by agreement on the product price, i. e. agreement on concertized exchange symmetry. Only this kind of exchange looks like the right autoregulator and driving power of desired development of market economy. States that free exchange realized by the relationship of purchase and sale is the exchange when both sides of the relationship purchaser and seller realize value added, benefit or profit. Otherwise the entry into market transactions is not free (Zelený, 2011).

When in the case of permanent disruption of market economy microstructure, obstruction of its effort of cyclic autoregulation this way it comes up to the disruption of relative dynamic balance of the relationship (Friedman 2002). The deformation of free exchange immediately makes deformation of autoregulative element TE, which leads to gradual destruction or unexpected collapse of the whole system or market economy. Current situation called financial and economic crisis could be perceived also with this optics (Sedláček, 2011).

\subsection{Crisis as a part of economic cycle}

Currently macroeconomic theory offers the view of the crisis, respectively recession as a standard part of economic cycle. For recession elimination and its origin various recommendations were formulated starting at state protectionism through massive state interventions to money reserve growth. It is possible to understand the recession positively (Zelený, 2011). The crisis is a certain part of economic development and has a cleaning effect. It deprives economy of useless and unsound, makes space for new ideas, companies and people. The government interventions as the base of financial crisis, which multiplies primary elements of the crisis, respectively recession which is encoded in markets and their attitudes (Kislingerová, 2010). 
The above description of free market axiom there is no possibility to perceive this current crisis as a crisis of capitalism or the free market doctrine (Smrčka, 2012). The main causes of that economic situation is possible to find in a big failure of free market regulation especially due to an unprecedented growth of state interventions into free market economy (Zelený, 2010).

\subsection{The global crisis and the World automotive industry (Al)}

During the crisis period in 2007 - 2010 as stated by agency report J. D. Power and Associates ${ }^{\circledR}$ (2009, 2010, 2011), it came up to rapid slump in most car categories. These categories are classified by J. D. Power and Associates ${ }^{\circledR}$ according to the length of the car, so called bodystyle (Conventional, MAV, SUV, Sporty, Van, Pick-up and according to so called Market Status (Economy, Non-Premium, Premium, Super-Premium). An individual chapter includes pick-ups, vans and lorries. In connection with the whole situation in automotive industry during the start of financial and economic crisis J. D. Power and Associates ${ }^{\circledR}(2009)$ states that the decrease of the whole production of cars was between the beginning of crisis to AP in 2008 and full crisis year 2009 in North America by ca. $35.2 \%$, in western Europe by $14.1 \%$, in eastern Europe by $24.6 \%$, in Japan by $31.3 \%$, in the region of Asia/Pacific it even came up to the growth by $21.0 \%$. In the group other countries (Australia, Columbia, Ecuador, Venezuela, Uruguay, Iran, Morocco, and northern Africa) it came up to the decline by $1.0 \%$. Worldwide it came up to year-on-year fall in car production by $11.2 \%$ (Sedláček, 2011). And how has this fall displayed in the Czech Republic automotive industry?

\subsection{Evaluation systems, competitiveness of economies and companies}

It is possible to understand the competitiveness as conditions' summary for reaching sustainable growth productivity and this way also growth of economic level in conditions of internal and external balance (Kislingerová, 2008). Currently there exist two main attitudes to interpretation of competitive ability and to the way of its evaluation. In the first case the evaluation of competitiveness based on market share is taken into consideration coming out of OECD attitude (Pavelková, 2009). The second attitude to measuring competitive ability based on the productivity (Kadeřábková \& Žd'árek, 2006). Who claims that competitiveness is not concetrated only on macroeconomic, law, political and social conditions, can also be joined with this attitude. Stabile environment only creates conditions and opportunities not wealth as such (Porter, 2008).

For the research needs the macroeconomic situation in this contribution was described with the indicators Gross Domestic Products (GDP). There were used GDP of the Czech Republic because all the companies were situated there and the Germany GDP because Germany was the biggest and most interesting market for all car producers in Europe.

As far as the company performance, its managing and corporate strategies concerned there have been already identified seven reasons why management of company performance is a dynamic system: (1) the changes of work; (2) increasing competition; (3) specific improvement initiatives; (4) national and international awards; (5) changing organizational roles; (6) changing external demands; (7) the power of information technology. These matters have become even more complicated, if not exacerbated, by the recent political and economic crises with a lot of impacts on company strategies and also performance (Chau, 2012). 
Standard concept of company strategies is possible to be defined as the ability of the company to reach its aims, its readiness to the future and company ability to face future world conditions (Dent, 2008), (Žáková-Talpová, 2011).

To face this situation many companies are working with some performance measures and there are a lot of different approaches to collected and termed them. There are four main types of performance measures: (1) Key Result Indicators (KRIs) that tell how the company has done in a perspective or critical success factor e.g. EBT, Return on Capital, Customer Satisfaction etc., (2) Result Indicators (RIs) tell what the company has done and they are the financial performance measures like Net Profit, Sales etc., (3) Performance Indicators (PIs) are nonfinancial indicators like percentage increase in sales top $10 \%$ customers, late deliveries etc. PIs and RIs lie between the KRIs and KPIs (4). KPIs are often described in theory as a set of measures focusing on those aspects of company performance that are the most critical for the current and future success (Parmenter, 2010).

Because of such reasons as the lack of incentives as well as an organizational culture unfavorable to performance measurement, some developing a performance measurement tool set involves a rather complicated process (Chae, 2009). Against the theory and the above decribed way of fission is the determination and accomplishment of these business strategies in most companies are observed by means of generally so called KPIs include financial (RIs) and nonfinancial measures (PIs) and so called Strategic Gap Analysis (SGA) (Sedláček, 2012). These measures are usually set internally in a different way in various companies. The author let the title of the measures which were used RIs for a better identification during the process of usage. Among used and in this contribution analysed company RIs belong for example the main Sales, Return on Assets (ROA), Earnings Before Taxes (EBT) etc. (Vemimmen, 2009).

\section{PROBLEM FORMULATION AND RESEARCH METHODOLOGY}

The research was carried in two levels so that it answered both below research questions. The first research problem was to answer whether it is true that the economy of the Czech Republic is highly dependent on productivity of the automotive industry sector. The second researched problem was then the fact concerning company corporate strategies when the author supposed that if the company strategy was successful then the company would reach similar results of chosen indicator without any regard to the progress of chosen indicator of macroeconomic surrounding mainly during crisis period 2007-2010.

\subsection{Research questions (RQs)}

RQ1: Is the economy of the Czech Republic represented with the chosen indicator Gross Domestic Product highly dependent on productivity of the automotive industry sector measured with the Result Indicator (RI) Sales?

RQ2: Were the chosen company strategies, respectively the chosen AutoSAP companies characterised with the RI Sales during the crisis period successful? 


\subsection{Research methodology}

For answering the first research question were used overall indicators of association AutoSAP, mainly the indicators of the whole sales rate (RI Sales) during chosen period $1999-2011$. There were used both the total indicator and the division of the companies in AutoSAP on suppliers and finishers. From the macroeconomic point of view the indicator GDP was chosen for the same period. To be able to compare there were used also other indicators representing the progress of AutoSAP respectively automotive industry sector in the Czech Republic.

For answering the second research question were chosen 10 important companies within association AutoSAP which were ranked with regard to the product portfolio. This choice was made so that within one group there were covered companies producing various products for AI starting at electronic products through light technology to mechanic products. From the research point of view the indicator RI Sales of individual companies was chosen and from the macroeconomic point of view the indicator GDP Czech Republic and GDP Germany. GDP Germany was chosen by the reason that it is the biggest market in the region Europe.

To represent yearly development of the indicators some chosen methods were used from so called elementary characteristics of time lines as calculations $1^{\text {st }}$ difference (year-on-year) and $2^{\text {nd }}$ difference. Further there were used calculations of growth rate or so called growth coefficients or line indexes and an average growth rate which is defined as geometric diameter from individual (here used early) growth rate. In the following part of the research the preparation for making correlation matrix was done using calculations of variability extent. For finding causal relationships among statistic marks there was used regressive and correlation analysis. For counting was used mostly used type so called Linear regression which was expressed with the help of mathematic entry of regressive line:

$y=A+B_{x}$

at estimate of Regressive and correlation analysis parameters $A, B$ according to patterns:

$A=\frac{\sum y-B \times \sum x}{n}$.

$B=\frac{n \times \sum x y-\sum x \times \sum y}{n \times \sum x^{2}-\left(\sum x\right)^{2}}$

Further based on input data there were used calculations of reciprocal correlation coefficients in so called correlation matrix. For calculation of coefficients $r$ was used pattern:

$r=\frac{n \times \sum x y-\sum x \times \sum y}{\sqrt{\left\{n \times \sum x^{2}-\left(\sum x\right)^{2}\right\} \times\left\{n \times \sum y^{2}-\left(\sum y\right)^{2}\right\}}}$

Further after calculation of correlation coefficients the calculation was done which was necessary for evaluation of subject importance of effect size of the group on variability of values observed random quantity according to so called Cohen's coefficient $d$. With the help of realization of weighted mean values of chosen dispersions: 
$s^{2}=\frac{\left(n_{1}-1\right) \times s_{1}^{2}+\left(n_{2}-1\right) \times s_{2}^{2}}{n_{1}+n_{2}-2}$.

which is used for observing of random quantity values in two independent groups of objects with extent $n_{1}, n_{2}$. Marking $m_{1}, m_{2}$ then had realizations of chosen mean values. Marked $s_{1}{ }^{2}, s_{2}{ }^{2}$ were realizations of chosen dispersions. Cohen's coefficient $\mathrm{d}$ was calculated according to pattern:

$d=\frac{\left|m_{1}-m_{2}\right|}{s}$.

Value $d$ determines the effect of the group on variability of quantity values in scale: $<0.2=$ neglible, $0.2-0.5=$ small effect, $0.5-0.8=$ middle and 0.8 and more $=$ big. These values refer to effect size when comparing mean values with respect to their variances.

\subsection{Restrictions of the main methods}

One of the aims for the choice and usage of these methods was to contribute to the recognition of reciprocal relationships between observed marks (RI Sales,) companies, AutoSAP as the whole and external macroeconomic surrounding (the Czech Republic and Germany as the biggest market) represented by the GDP indicator. Particularly the method of regressive and correlative analysis is usable and used for this type of economic research. It is important to mention that this method has its certain restrictions. One of the major restrictions seems to be the choice of suitable type of regress function (in work chosen Linear regression) and also the fact that the analysis of numbers can only limitedly cover the whole substance of researched economic quantities and phenomenon as on the level of micro so in macro surrounding. Restrictions of correlation is the fact that correlation is a statistic term for expressing the extent of some linear relationship and it concerns the term measurement. The cause and consequence concern deterministic dependence. It is important to analyse and explain causal connections. Cohen's coefficient $d$ was used to assess the size of the difference of mean values which is standardized with the help of root from the mean values of chosen scatters. It concerns so called subject importance. The size of the group effect on value variability of observed quantity is then evaluated according to the line of values of $d$. The strength of the test should reach the figure at least 0.8 . Figures between $0.5-0.8,0.2-0.5$ and 0.2 mean falling effect.

\section{THE RESULTS}

For carrying out the research in the most interested period 2007 - 2010 while using above described methods there were chosen values of indicator RI Sales (mil. CZK, yearly). In comparison with the development of macro-surrounding in the form of regression and correlation analysis then GDP CZ and GDP GE (in mil. CZK and $€$, year periods). Due to the usage of basic macroeconomic data of the Czech Republic at this type of research it was important to pay adequate attention to these indicators. Further in this part of the article data (RI Sales AutoSAP finishers, suppliers, chosen companies) was analyzed, their reciprocal relationships and further relevant discovery. This researches were made during longer time before above mentioned (07 -10) and at the same time the following (2011) was included. 


\subsection{The Czech Republic Gross Domestic Product 1999 - 2011}

The graphic illustration of indicator GDP Czech Republic 1999 - 2011 shows the progress of this indicator in constant prices (2005) both in absolute values and index illustration were demonstrated (Fig. 1).

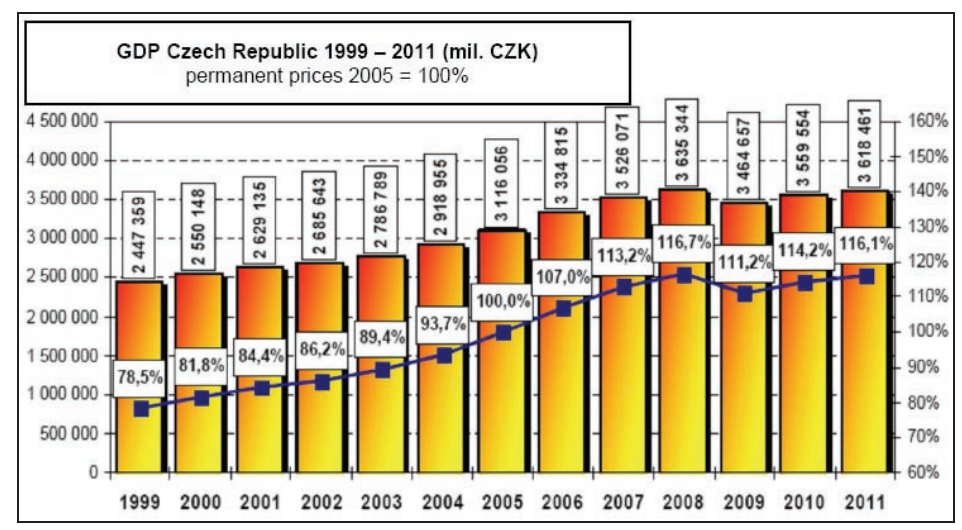

Fig. 1 - The Czech Republic GDP 1999 - 2011. Source: AutoS AP, 2012.

Indexes of year-on-year GDP growth $(2000$ - 11) are illustrated in Fig. 2. There were again used permanent prices based on the year 2005 and at the same time period common index prices.

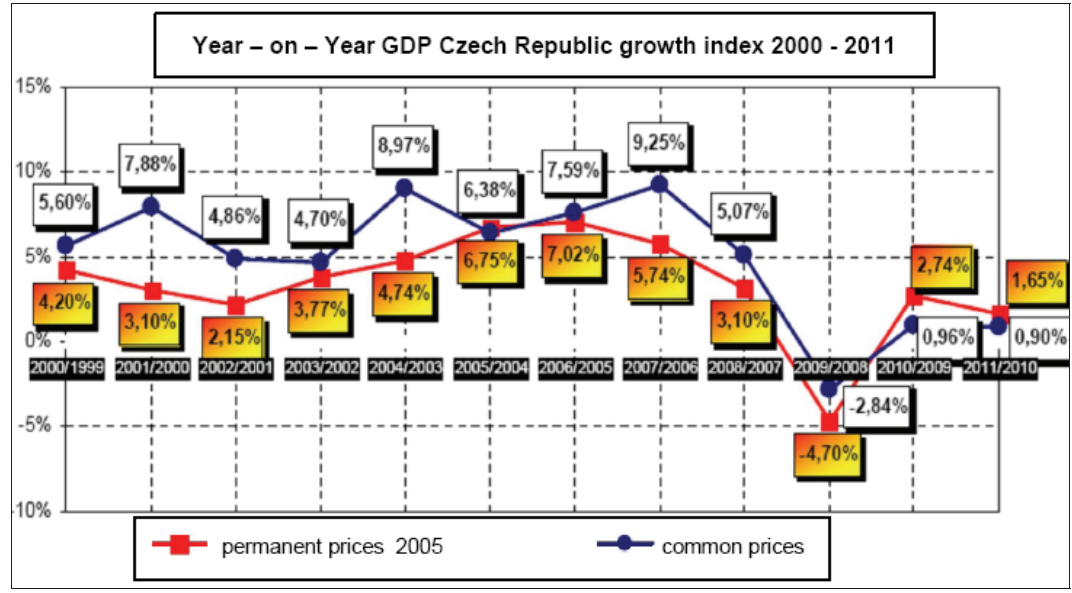

Fig. 2 - The GDP of the Czech Republic, 2000 - 2011 Year-on-Year. Source: AutoS AP, 2012.

\subsection{The Czech Republic Industrial Production 2000 - 2011}

In Fig. 3 then with the usage of absolute values of indicator Sales in sum we can see graphically illustrated development of indicators during 2000 - 10. It demonstrates the progress of the indicator Industrial Production CZ in sum, the progress for the companies in AI associated in AutoSAP and sales share of AutoSAP on the whole industrial production. 


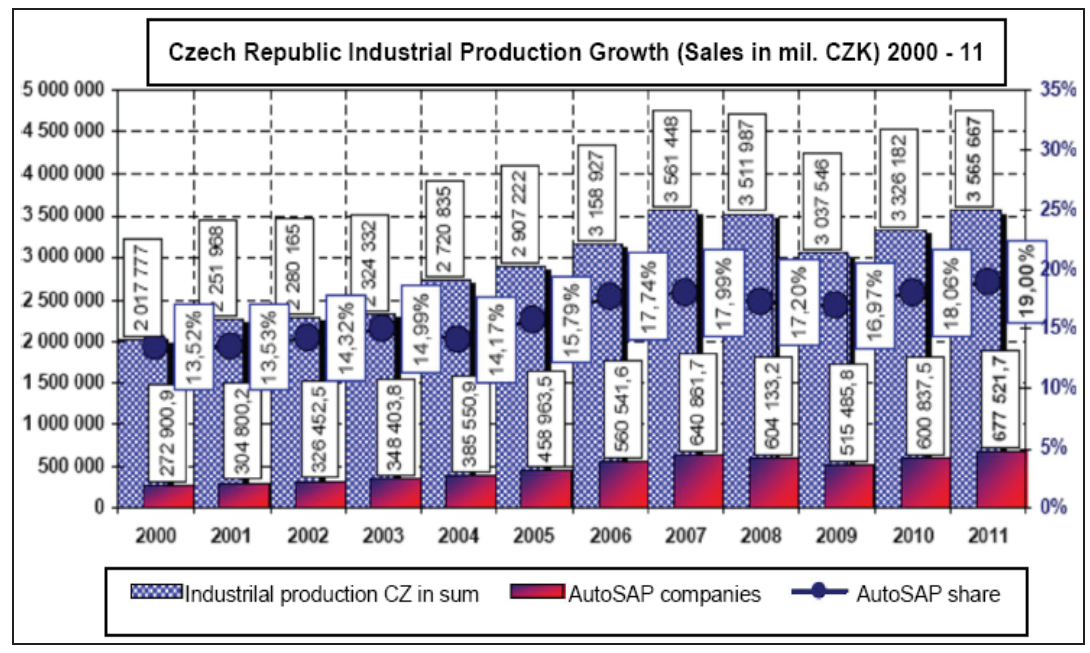

Fig. 3 - The Industrial Production of the Czech Republic (Growth of Sales). Source: AutoS AP, 2012.

Indexes of year-on-year indicator growth of industrial production Sales in the Czech Republic and companies associated in AutoSAP during $2000-2011$ is illustrated Fig. 4.

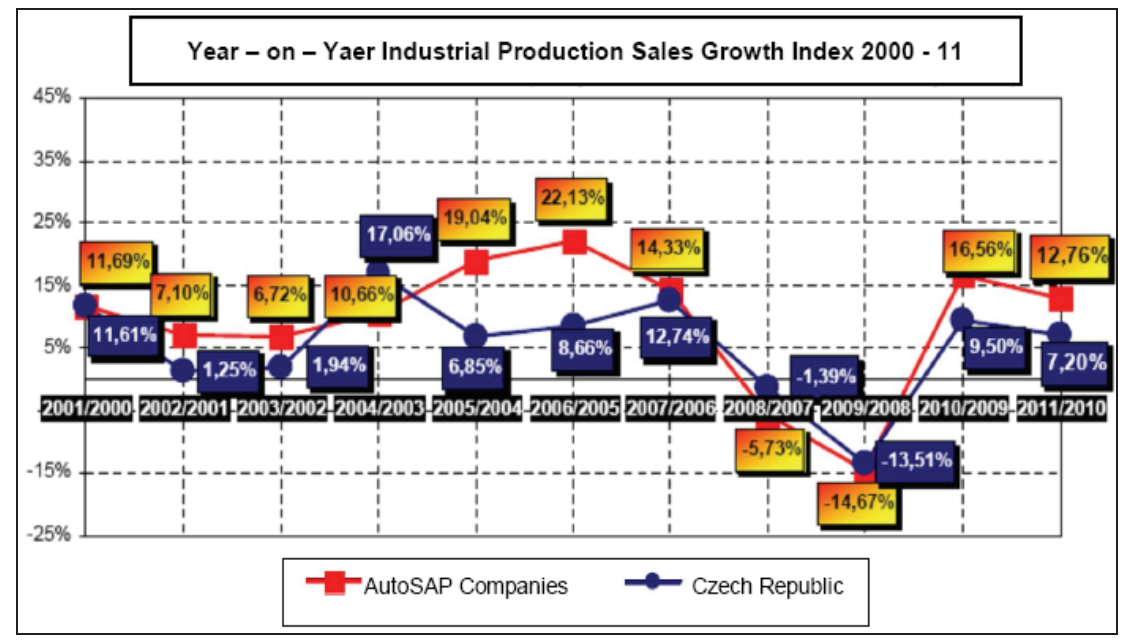

Fig. 4 - Year-on-Year Industrial Production Sales Growth Index. Source: AutoS AP, 2012.

\subsection{The relationship between the AutoSAP Sales and the Czech Republic GDP}

For analysis of AutoSAP RI Sales $\left(\mathrm{SAP}_{\mathrm{f}}, \mathrm{SAP}_{\mathrm{s}}, \mathrm{SAP}_{\mathrm{f}+\mathrm{s}}\right)$ and the Czech Republic GDP regressive and correlation analysis was used which came out from so called the tab for correlation (Tab 1.) . Year values of the AutoSAP companies $\left(\mathrm{SAP}_{\mathrm{f}}, \mathrm{SAP}_{\mathrm{s}}, \mathrm{SAP}_{\mathrm{f}+\mathrm{s}}\right)$ in the Tab. 1 represent the indicators RI Sales in bill. CZK and GDP Czech Republic also in bill. CZK. 
Tab. 1 - RI Sales AutoSAP and CZ GDP. Source: own survey.

\begin{tabular}{|c|c|c|c|c|}
\hline \multicolumn{5}{|c|}{ Sales in sum AutoSAP Companies and CZ GDP * [10 CZK $] 1999-2011$} \\
\hline Period & $\begin{array}{c}\text { Sales in sum } \\
\text { AutoSAP - } \\
\text { Finishers }\left(\mathbf{S A P}_{\mathbf{f}}\right)\end{array}$ & $\begin{array}{c}\text { Sales in sum } \\
\text { AutoSAP - } \\
\text { Suppliers }\left(\mathbf{S A P}_{\mathbf{s}}\right)\end{array}$ & $\begin{array}{l}\text { Sales in sum } \\
\text { AutoSAP - } \\
\text { Companies } \\
\left(\mathbf{S A P}_{\mathrm{f}+\mathrm{s}}\right)\end{array}$ & $\begin{array}{c}\text { GDP Czech } \\
\text { Republic }\end{array}$ \\
\hline $\mathbf{P} 1_{(99)}$ & 101,7 & 52,8 & 154,5 & 2447,4 \\
\hline $\mathbf{P 2}{ }_{(00)}$ & 115,8 & 69,6 & 185,4 & 2550,1 \\
\hline P3 $(01)$ & 117,3 & 100,8 & 218,1 & 2629,1 \\
\hline $\mathbf{P 4}{ }_{(02)}$ & 149,0 & 122,4 & 271,3 & 2685,6 \\
\hline P5 (03) & 159,3 & 144,6 & 303,9 & 2786,8 \\
\hline P6 $(04)$ & 158,3 & 167,0 & 325,3 & 2919,0 \\
\hline P7 ${ }_{(05)}$ & 148,3 & 198,9 & 347,2 & 3116,1 \\
\hline P8 ${ }_{(06)}$ & 157,7 & 226,6 & 384,2 & 3334,8 \\
\hline \begin{tabular}{|l} 
P9 \\
$(07)$ \\
\end{tabular} & 186,8 & 271,3 & 458,1 & 3526,1 \\
\hline P10 ${ }_{(08)}$ & 259,0 & 337,8 & 596,7 & 3635,3 \\
\hline P11 ${ }_{(09)}$ & 267,7 & 240,4 & 508,1 & 3464,7 \\
\hline P12 ${ }_{(10)}$ & 312,5 & 279,4 & 591,9 & 3560,0 \\
\hline P13 ${ }_{\text {(11) }}$ & 357,1 & 309,9 & 666,9 & 3618,5 \\
\hline$\Sigma$ & 2490,4 & 2521,3 & 5011,7 & 40273,4 \\
\hline
\end{tabular}

Later to the input data there were additionally calculated values of dispersion $s^{2}$, values of determinant margin of error square root of dispersion $s, A$ according to (2), $B$ according to (3). It was necessary to find out the estimates of parameters $A$ and $B$ so that they could later be substituted to the equations of regress lines of all AutoSAP categories from which the model was formed. Afterwords correlation coefficients $r$ were calculated according to (4). The number of periods $\mathrm{P}$ was reduced to altogether 13 i.e. year intervals. After calculation of correlation coefficients there were used existing estimates of parameters $A$ and $B$ according to (2) and (3) were created regressive lines according to (1). The model of regressive lines interpreted the values. The linear model represents dependencies between values of RI Sales of companies the AutoSAP $\left(\mathrm{SAP}_{\mathrm{f}}, \mathrm{SAP}_{\mathrm{s}}\right.$, $\left.\mathrm{SAP}_{\mathrm{f}+\mathrm{s}}\right)$ vs. the Czech Republic GDP 1999 - 2011.

Linear Regression Sales AutoSAP(s;f;f+s) vs. GDP CZ

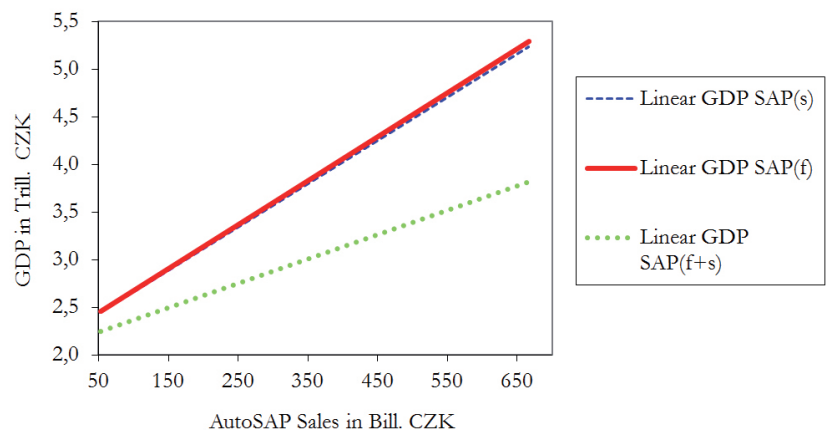

Fig. 5 - Linear Regression Lines AutoS AP RI Sales vs. CZ GDP. Source: own survey. 
The test of linear dependence with the help of regressive and correlation analysis represents model relationship (Fig. 5) among researched values which are:

$y_{1}=2,21+4,62 * \frac{S A P_{(f)}}{10^{6}} \quad\left(r_{l}=0,84 ; \mathrm{n}=13\right)$

$y_{2}=2,2+4,55 * \frac{S A P_{(s)}}{10^{6}} \quad\left(r_{2}=0,98 ; \mathrm{n}=13\right)$

$y_{3}=2,11+2,56 * \frac{S A P_{(f+s)}}{10^{6}}\left(r_{3}=0,96 ; \mathrm{n}=13\right)$

where $y_{1}, y_{2}, y_{3}$ represent the values of GDP in relationship to the indicators RI Sales of the AutoSAP companies finishers - $\mathrm{SAP}_{(\mathrm{f})}$, suppliers $\mathrm{SAP}_{(\mathrm{s})}$ and AutoSAP finishers and suppliers altogether $\mathrm{SAP}_{(\mathrm{f}+\mathrm{s})}$. The results of this research were used as a base for the discussion concerned the RQ1. The following research was aimed to answer the RQ2.

\subsection{The relationships between Sales of the AutoSAP Chosen Companies and GDP CZ}

To answer the second research questions (RQ2) it was necessary to carry out the research focused on the relationship of indicator Sales of chosen companies of association AutoSAP and macroeconomic indicator GDP Czech Republic. Supposing that major part of the AutoSAP companies is oriented at German market, the indicator GDP DE was also included in this research. The criteria for the choice of the companies were to cover portfolio of products for automotive industry from various subbranches. In the ten mentioned companies electronics, light technology, products or sets from metal parts, rubber industry and also oil products were included. The best companies were chosen based on the sales volume. For the analysis of relationships between Result Indicators (RI Sales) of the AutoSAP companies marked Co.1, Co.2,...Co.9, Co. 10, $\varnothing$ Co. and GDP CZ, GDP DE regressive and correlation analysis was used once again. The analysis was based on the figures mentioned in the Tab. X where indicator values are indicated for individual years of researched period 2002 - 2011. As well there are mentioned individual values of macroeconomic indicator Gross Domestic Product (GDP CZ, GDP DE). All RI Sales AutoSAP indicators are used in billion CZK, the indicators GDP than in billions of national currencies (CZK, EUR).

Tab. 2 - AutoSAP chosen companies RI Sales and CZ GDP. Source: own survey.

\begin{tabular}{|c|c|c|c|c|c|c|c|c|c|c|c|c|c|}
\hline \multirow[b]{2}{*}{$\mathrm{n}$} & \multicolumn{10}{|c|}{ Company Sales (in. Bill. CZK) 2002 - 2011} & \multirow{2}{*}{$\begin{array}{c}\text { GDP } \\
\text { CZ (Bill. } \\
\text { CZK) }\end{array}$} & \multirow{2}{*}{$\begin{array}{c}\text { GDP } \\
\text { DE (Bill. } \\
\text { EUR) }\end{array}$} & \multirow{2}{*}{$\begin{array}{c}\varnothing \\
\text { Co. }\end{array}$} \\
\hline & Co. 1 & Co. 2 & Co. 3 & Co. 4 & Co. 5 & Co. 6 & Co. 7 & Co. 8 & Co. 9 & Co. 10 & & & \\
\hline P1 & 26,1 & 9,2 & 11,8 & 9,0 & 9,3 & 3,7 & 8,0 & 2,7 & 2,7 & 2,1 & 2685,6 & 2132,2 & 8,5 \\
\hline $\mathrm{P} 2$ & 26,8 & 9,5 & 13,9 & 9,3 & 9,3 & 4,0 & 8,0 & 3,0 & 2,8 & 2,3 & 2786,8 & 2147,5 & 8,9 \\
\hline P3 & 27,6 & 9,9 & 17,2 & 10,5 & 10,1 & 5,1 & 10,1 & 3,2 & 3,6 & 2,7 & 2919,0 & 2195,7 & 10,0 \\
\hline P4 & 27,7 & 10,2 & 18,9 & 10,8 & 8,9 & 5,9 & 10,3 & 6,7 & 4,8 & 2,6 & 3116,1 & 2224,4 & 10,7 \\
\hline P5 & 29,6 & 9,9 & 21,7 & 11,6 & 8,8 & 5,7 & 9,8 & 9,2 & 0,5 & 2,4 & 3334,8 & 2313,9 & 10,9 \\
\hline P6 & 30,9 & 9,6 & 22,9 & 11,7 & 9,5 & 5,3 & 10,0 & 9,4 & 0,4 & 2,6 & 3526,1 & 2428,5 & 11,2 \\
\hline
\end{tabular}




\begin{tabular}{|c|c|c|c|c|c|c|c|c|c|c|c|c|c|}
\hline P7 & 26,5 & 7,9 & 19,6 & 8,6 & 8,1 & 4,7 & 8,2 & 9,8 & 0,6 & 4,4 & 3635,3 & 2473,8 & 9,8 \\
\hline P8 & 24,2 & 7,1 & 12,7 & 8,1 & 7,8 & 3,9 & 7,5 & 8,8 & 0,6 & 3,8 & 3464,7 & 2374,5 & 8,5 \\
\hline P9 & 29,8 & 30,3 & 17,1 & 9,9 & 8,4 & 3,8 & 7,6 & 7,6 & 0,6 & 4,5 & 3560,0 & 2496,2 & 12,0 \\
\hline P10 & 33,5 & 36,8 & 17,2 & 11,2 & 9,7 & 5,1 & 7,7 & 7,6 & 0,8 & 4,7 & 3618,5 & 2592,6 & 13,4 \\
\hline$\Sigma x$ & 282,6 & 140,3 & 173,2 & 100,9 & 89,9 & 47,0 & 87,2 & 68,0 & 17,3 & 32,2 & 32646,8 & 23379,3 & \\
\hline
\end{tabular}

Later to the input data there were additionally calculated values s $\mathrm{s}^{2}, s, A$ according to (2), $B$ according to (3). It was necessary to find out the estimates of parameters $A$ and $B$ so that they could later be substituted to the equations of regress lines of all companies from which the model was formed. Afterwords correlation coefficients $r$ were calculated in correlation matrix 13 x 13 according to (4) for AutoSAP companies Co. 1-10, GDP CZ, GDP DE and the average value of all the AutoSAP companies. The values of correlations made the lower triangle matrix in the Tab. 3. Cohen's coefficients $d$ according to (5) and (6) for altogether 10 companies was used for the test criteria calculation so that it could be possible to vet midd difference values by the AutoSAP companies average value. The values Cohen's coefficients values were mentioned in the upper part of the triangle matrix. The number of periods $\mathrm{P}$ was reduced to altogether 10 i.e. year intervals. These calculations and results of correlation coefficients are stated in Tab 3.

Tab. 3 - Correlation and Cohenś Coefficients Co. Sales vs CZ GDP. Source: own survey

\begin{tabular}{|c|c|c|c|c|c|c|c|c|c|c|c|c|c|c|}
\hline \multicolumn{15}{|c|}{ Correlation and Cohenś Coefficients Sales vs. GDP CZ and GDP DE } \\
\hline Period & Co. 1 & Co. 2 & Co. 3 & Co. 4 & Co. 5 & Co. 6 & Co. 7 & Co. 8 & Co. 9 & Co. 10 & $\begin{array}{c}\text { GDP } \\
\text { CZ }\end{array}$ & $\begin{array}{c}\text { GDP } \\
\text { DE }\end{array}$ & $\begin{array}{c}\varnothing \\
\text { Co. }\end{array}$ & \\
\hline $\begin{array}{l}\text { Co. } 1 \\
\end{array}$ & 8 & 1,96 & 5,26 & 9 & 10,2 & 12,4 & 9,9 & 8,2 & 12,6 & 12,9 & & & 8,5 & \\
\hline Co. 2 & 0,74 & $>$ & 0,44 & 0,56 & 0,71 & 1,3 & 0,75 & 0,99 & 1,7 & 1,5 & & & 0,51 & \\
\hline Co. 3 & 0,54 & 0,02 & 8 & 2,8 & 3,3 & 5 & 3,3 & 3,4 & 5,8 & 5,5 & & & 2,6 & \\
\hline Co. 4 & 0,81 & 0,3 & 0,73 & $\sum$ & 1,1 & 5,3 & 1,2 & 1,6 & 6,1 & 6,2 & & & 0,22 & 3 \\
\hline Co. 5 & 0,48 & 0,17 & 0,1 & 0,59 & 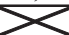 & 5,8 & 0,3 & 1,1 & 6,2 & 6,9 & & & 1,2 & 5 \\
\hline Co. 6 & 0,46 & $-0,07$ & 0,78 & $\begin{array}{ll}0,77 \\
\end{array}$ & 0,31 & 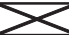 & 4,2 & 1,1 & 2,5 & 1,7 & & & 4,7 & 赵 \\
\hline Co. 7 & 0,16 & $-0,41$ & 0,66 & $\begin{array}{ll}0,67 \\
\end{array}$ & 0,42 & 0,82 & 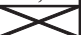 & 0,9 & 5,3 & 6,7 & & & 1,3 & 8 \\
\hline $\begin{array}{ll}\text { Co. } 8 \\
\end{array}$ & 0,28 & 0,11 & 0,63 & 0,19 & $-0,57$ & 0,34 & 0,03 & $<$ & 2,3 & 1,3 & & & 1,6 & 8 \\
\hline Co. 9 & $-0,3$ & $-0,29$ & $-0,27$ & 0,01 & 0,41 & 0,19 & 0,42 & $-0,71$ & $<$ & 1,2 & & & 5,7 & \\
\hline Co. 10 & 0,28 & 0,66 & 0,03 & $-0,2$ & $-0,41$ & $-0,19$ & $-0,57$ & 0,52 & $-0,54$ & 8 & & & 5,6 & \\
\hline GDP CZ & 0,44 & 0,43 & 0,52 & 0,16 & $-0,45$ & 0,2 & $-0,18$ & 0,91 & $-0,75$ & 0,78 & & & & \\
\hline GDP DE & 0,58 & 0,66 & 0,4 & 0,17 & $-0,88$ & 0,09 & \begin{tabular}{|l|}
$-0,33$ \\
\end{tabular} & 0,76 & $-0,75$ & 0,87 & 0,95 & & & \\
\hline Ø Co. & 0,94 & 0,81 & 0,57 & 0,72 & 0,27 & 0,47 & 0,11 & 0,41 & $-0,3$ & 0,5 & 0,6 & 0,71 & & \\
\hline
\end{tabular}

After calculation of correlation coefficients $r$ there were used existing estimates of parameters $A$ and $B$ according to (2) and (3) were created regressive lines according to (1). The model of regressive lines interpreted their values. 


\section{Linear Regression Lines Sales AutoSAP Co.1-10 in period 2002 - 2011}

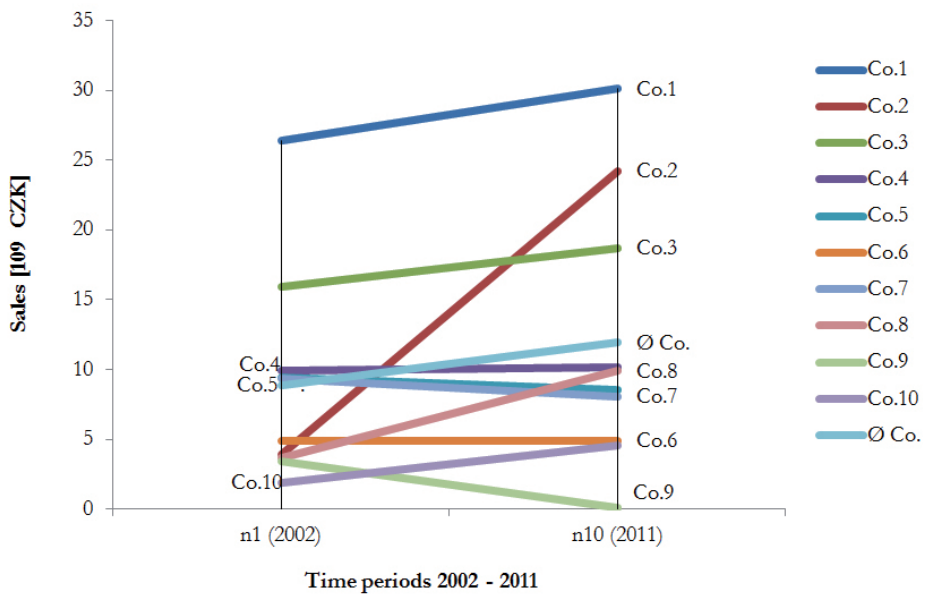

Fig. 6 - Liner Regression Lines Co. RI Sales AutoS AP vs. Time Periods. Source: own survey.

\section{DISCUSSION}

In the part 3.1 so called Research Questions $\left(R Q_{1}, R_{2}\right)$ were introduced and for their answering were performed chosen types of analyses in other parts of the article. To acquire general knowledge about the state of macroeconomic surrounding respectively productivity of the Czech economy, in the part 4.1 was used graphic illustrated progress of the GDP Czech Republic indicator in the years 1999-2011. Both the values of absolute height of GDP indicator and progress of year-on-year growth indexes were used. Mentioned diagrams (Fig. 1, Fig.2) illustrate permanent growth of GDP index. According to Fig. 2 GDP grew from years 200/99 (year 2000 minus year 1999 ) to $2004 / 03$ gradually (growth rate: $-4 \%$ per period). From years $2005 / 04$ growth by c. a. $7 \%$ per year came to the years 2008/07. After the year 2008 then comes to the decline in productivity of the Czech economy (impacts of the worldwide economic recession). The fact coming out of the mentioned data is that the economic productivity of the year 2008 level was not reached even in 2011. After the period of year-on-year slump 2009/08 (-5.5\%) came up to slight growth by 3\% (2010/09) respectively 1.9\% (2011/10).

As for the industrial production in the Czech Republic (expressed by sales volume) in the Fig. 3 it is possible to see the growth of absolute values from year 2000 to year 2004. Afterwards from 2005 it comes up to the growth of absolute values with the top in the year 2007 and stagnation in 2008. Rapid slump hit in the year 2009 followed by the growth to the before crisis level in 2011 in the whole sales volume from industrial production to level 3.565 .557 mil. CZK. The companies associated in AutoSAP representing automotive industry from c. a. $85-90 \%$ then in 2011 reached higher sales level than in before crisis period. In 2011 the companies associated in AutoSAP reached the sales from industrial production 677.521 .7 mil CZK which is by $12.7 \%$ more than in 2010. Since the sales volume from industrial activity in the Czech Republic grew by $7.2 \%$ in total we can claim that involvement of the companies associated in AutoSAP in total 
sales from industrial activity of the Czech Republic grew up by c. a. 1\% compared with the year 2010. Within the whole automotive industry of the Czech Republic it was discovered that its involvement in industrial production (sales from industrial activity) exceeded the value $22.0 \%$. Comparing years 2011/10 (2011minus 2010) the automotive production of the Czech Republic grew up by $12.53 \%$. Year-on-year production decline of companies AutoSAP has been recorded only three times since 1993. Between years 1994/93 it made 15.38\%, between years 2009/08 the led to $14.67 \%$. The years 1994 and 2009 were the most difficult ones for the Czech automotive industry. Based on the researches it was found out that the companies involved in AutoSAP activity represent more than $85 \%$ of the production of the whole automotive industry in the Czech Republic. This share is in fact stable. The automotive industry then participated on the industrial production growth of the Czech Republic totally 36.90\% in 2011.

For finding the answer to $\mathrm{RQ}_{1}$ was used further research method which is described in part 4.3. Regression and correlation analysis was used for this type of research. With its help we looked for possible relationship respectively dependency of GDP Czech Republic on indicator RI Sales of the companies associated in AutoSap and representing automotive industry in the Czech Republic. In Tab. 1 there are stated above mentioned indicators RI Sales for AutoSAP - Finishers (final products), AutoSAP Suppliers (not final products), AutoSAP Companies (Finishers + Suppliers) and indicators GDP Czech Republic during 1999-2011 which is period $\mathrm{n}=13$. All data in mil. CZK. By calculation of correlation coefficients there was discovered strong correlation dependency of macro indicator of economic productivity GDP Czech Republic on indicators RI Sales of the companies associated in AutoSAP. Closeness of the relationship of indicator GDP Czech Republic and AutoSAP Finishers is expressed by correlation coefficient $r_{1}=0,84$. GDP Czech Republic and AutoSAP Suppliers then $r_{2}=0,98$. GDP Czech Republic and AutoSAP Companies (Finishers + Suppliers) then $r_{3}=0,96$. These close linear dependencies are graphically illustrated in Fig. 5.

From the above mentioned researches and achieved results it is possible to answer the question RQ1 that the economy of the Czech Republic is highly dependent on the productivity of the automotive industry sector. This statement was supplemented by data acquired by calculations made in part 4.4 .

To answer the research question $\mathrm{RQ}_{2}$, that means whether chosen company strategies respectively companies in crisis period were successful, the indicator of their productivity RI Sales was again chosen, macroeconomic GDP Czech Republic (GDP CZ) and GDP Germany (GDP DE) as the biggest on automotive market in Europe during specified period. Of course for the company performance could be used more than this indicator. The base was data in the input tab (Tab.2). This data illustrate the development of indicator RI Sales of ten companies from association AutoSAP, Ø Co. AutoSAP and indicators GDP Czech Republic and GDP Germany during $2002-2011$ with equidistant step of one year from marked periods $t=\mathrm{P} 1, \mathrm{P} 2, \ldots \mathrm{P} 10$. It is possible to say that the progress of indicator RI Sales by Co.1, Co.2,..., Co.6, Co.10 is in fact identical respectively growing from period P1 (2002) to period P6 (2007) with following slump in P7 (2008) and then growth in P8 (2009), P9 (2010), P10 (2011). On the other hand Co.7, Co.8 and Co.9 have different indicator RI Sales. There were made also calculations of average $\mathrm{m}$ value, dispersion $s^{2}$ and regression lines including correlation coefficients $r_{11}, r_{12}, \ldots r_{1313}$ and estimated equations of regression lines of indicator progress RI Sales during researched period. Fig.6 rep- 
resents regression lines of sales progress of chosen companies AutoSAP during 2002-2011.

The indicators RI Sales of the AutoSAP companies and their relationships to external macro surrounding were also researched in the part 4.4. For finding the existence of the relationships between company (RI Sales) and macro indicator (GDP) of the Czech Republic and the biggest market (DE) was also used the Tab. 2 as a data source.

Calculated values made the correlation matrix (Tab. 3). It means that calculation of correlation coefficients of chosen companies AutoSAP (Co.1, ...Co.10) was made, Ø Co. AutoSAP, GDP Czech Republic and GDP Germany. Calculated values correlation coefficients $r_{1,1}, \ldots r_{13 ; 13}$ made lower triangular matrix in Tab.3. From which it is possible to read the values of correlation respectively correlation coefficients both among chosen companies AutoSAP mutually and among companies AutoSAP and $\varnothing$ AutoSAP or among companies AutoSAP and GDP CZ, GDP DE. At the same time there was claculated correlation Coefficient among GDP CZ and GDP DE. It is worth noticing that for example values $r_{2 ; 1}=0.74$ between Co.1 and Co.2, $r_{4 ; 1}=0.81$ between Co.1 a Co.4, $r_{13 ; 1}=0,94$ between Co.1 and $\varnothing$ AutoSAP which mean close relationship among these companies respectively $\varnothing$ AutoSAP. On the other hand $r_{11 ;}=0.44$ and $r_{12 ; 1}=0.58$ express less close relationship between Co.1 and GDP CZ respectively GDP DE. It is possible to proceed when analyzing correlation coefficients by all other companies. It is interesting that the result of the correlation coefficient $r_{12,11}=0.95$ thus positive, strong correlation dependency between GDP CZ a GDP DE. This discovery supports the statement about the dependency of the Czech export on production of German economy. At the same time it is possible to evaluate $r_{13 ; 1}=0.6$ and $r_{13 ; 12}=0.71$ as strong correlation dependency of indicators RI Sales $\varnothing$ AutoSAP and GDP CZ resp. GDP DE. On the other hand the existence of $r$ close to 0 does not have to necessarily represent non-existence of the relationship, only of linear dependency. Calculation of tested criteria (The Cohenś Coefficient) was made only for evaluation of difference size of mean values and average value AutoSAP. Calculated values fill in upper part of triangular matrix in Tab.3. Statistic importance is possible to be evaluated according to the defined zone in 3.2 (e. g. $d \geq 0,2$ means negligible difference of mean values). E. g. the value of Cohenś Coefficient $d_{1 ; 9}=$ 12,6 between the company Co.1 and Co.9 means that these companies are comparable. On the contrary at $d_{5 ; 7}=0.3$ between Co.5 and Co.7 it means that there is no statistic difference among these companies according to Cohen.

From carried researches it is possible to answer the research question $R Q_{2}$ in the way that by all research companies it came up to the decrease of value of RI Sales indicator during 2008/07 and 2009/08. It can be stated that chosen corporate strategies were not sufficiently flexible and companies AutoSAP were not ready for this macroeconomic situation in advance. In 2010/09 by most researched companies it came up to the return of growth with the exception of companies Co.6, Co.8 a Co.9. Later even these grew during the following period. The question for the following research remains whether the growth during these periods was caused by the change in corporate strategies or by entrepreneurial models or by state interventions into automotive industry in various countries, mainly in Germany. 


\section{CONCLUSION}

This article has introduced relatively simple and effective attitude towards looking for the answers to asked research questions. The first concerned possible dependency of the economy of the Czech Republic, represented by indicator GDP on productivity of automotive industry sector respectively its highly important part i. e. companies associated in association AutoSAP CZ. The second research question concerned readiness of researched companies or their corporate strategies for crisis period connected with the worldwide economic crisis from years 2007-2010. The companies form association AutoSAP and all relationships were researched from the point of view of one of the company productivity top indicators - RI Sales. After carried out research and with the usage of chosen methods it is possible to point out high dependency of the Czech economy respectively values GDP of automotive industry sector. At the same time it is possible to point out low readiness respectively ineffectiveness of accepted corporate strategies in researched companies on external economic situation. By extending used methods (GUHA) it will be possible to use the results in the future research works.

\section{Acknowledgement}

Author is thankful to the Internal Grant Agency of FaME TBU No. IGA/FaME/2012/042 (Podniky krizi navzdory) for financial support to carry out this research.

\section{References}

1. Dent, H. S. (2008). The Great Depression Ahead: How to Prosper in the Crass Following the Greatest Boom in History. New York: Free Press.

2. Frieman, M., \& Friedman, D. R. (2002). Capitalism and Freedom. Chicago: The University of Chicago Press.

3. Chae, B. K. (2009). Developing Key Performance Indicators for Supply Chain: In Industry Perspective. Supply Chain Management Journal, 14(6), 422-428. http://dx.doi.org/10.1108/1359 8540910995192

4. Chau, V. S. (2012). Managing Performance in Global Crisis. British Journal of Management, 23(S1), S1-S5. http://dx.doi.org/10.1111/j.1467-8551.2012.00825.x

5. Kadeřábková, A., \& Žd’árek, V. (2006). Makroekonomická analýza. Praha: Vysoká škola ekonomie a managementu.

6. Kislingerová, E. (2008). Inovace nástrojů ekonomiky a managementu organizací. Praha: C. H. Beck.

7. Kislingerová, E. (2010). Podnik v časech krize. Praha: Grada Publishing.

8. Parmenter, D. (2010). Key Performance Indicators: Developing, Implementing and Using Winning KPIs. New Jersey: John Wiley \& Sons.

9. Sedláček, M. (2011). Dopady globální krize na výkonnost podnikư. Doctoral dissertation theses. Zlín: Tomas Bata Univesity in Zlín.

10. Sedláček, M. (2012). Key Performance Indicators as a Business Strategy Tool during the Global Crisis Period. In Business and Economics Series (Ed.), Advances in Economics, Risk Management, Political and Law Science. Proceedings of the 1st WSEAS International Conference on Economics, Political and Law Science 2012 (pp. 136 - 141). WSEAS Press.

11. Smrčka, L. (2012). Increasing Threat of a Total Financial Crisis in the Upcoming Years. International Journal of Mathematical Models and Mothods in Applied Sciences, 6(1), 782-790. 
12. Vemimmen, P. (2009). Corporate Finance: Theory and Practise. Chichester: John Wiley.

13. Vrecion, V. (2008). Teorie managementu a správy. Zlín: Univerzita Tomáše Bati ve Zlíně.

14. Zelený, M. (2011). Hledání vlastní cesty. Brno: Computer Press.

15. Žáková-Talpová, M. (2011). Strategies of Domestic and Multinational Firms in the Czech Republic. Journal of Competitiveness, 3(4), 39-50.

\section{Contact information}

Ing. Marek Sedláček

Tomas Bata University in Zlin, Faculty of Management and Economics

Mostni 5139, 76001 Zlín, Czech Republic

Email:msedlacek@fame.utb.cz. 